\title{
Highly aggressive squamous cell carcinoma in an HIV-infected patient
}

\author{
Carcinoma de células escamosas altamente agressivo \\ em um paciente HIV-positivo
}

\author{
Rogerio Neves-Motta ${ }^{1}$, Fernando Raphael de Almeida Ferry ${ }^{1}$, Carlos Alberto \\ Basílio-de-0liveira ${ }^{2}$, Ricardo de Souza Carvalho ${ }^{3}$, Carlos José Martins ${ }^{3}$, \\ Walter A. Eyer-Silva ${ }^{1}$ and Carlos Alberto Morais-de-Sá ${ }^{1}$
}

\begin{abstract}
Unusually aggressive forms of cutaneous squamous cell carcinoma are being increasingly recognized as a complication of HIV infection. We report the case of a 59-year-old male patient with advanced HIV infection who presented with a highly aggressive SCC lesion over the scalp area with destruction of the underlying parietal bone and fulminant clinical progression.
\end{abstract}

Key-words: HIV infection. Squamous cell carcinoma.

\section{RESUM0}

Formas altamenteagressivas de carcinoma cutâneo decélulas escamosas vêm sendo reconhecidas como uma importante complicação da infecção pelo HIV. Descrevemos o caso de um paciente do sexo masculino, de 59 anos, que se apresentou com uma lesão altamente agressiva de SCC na região do couro cabeludo, com destruição do osso parietal subjacente e curso clínico fulminante.

Palavras-chaves: HIV/Aids. Carcinoma espino-celular. Carcinoma de células escamosas.

Cutaneous squamous cell carcinoma ( SCC), also known as epidermoid carcinoma, is a malignant neoplasm of the keratinizing epidermal cells and accounts for around one-ifth of all cases of nonmelanoma skin cancer ${ }^{1}$. Important etiologic factors to the development of SCC are host characteristics, such as age and skin pigmentation, and environmental elements, the most important of which beinglong-term sunlight exposure ${ }^{8}$. Actinic keratosis is known to be a major precursor lesion of $\mathrm{SCC}^{15}$. Other predisposing factors include ionizing radiation, such as therapywith ultravioletA, exposure to chemical carcinogens, especially arsenic, and long-standing benign dermatoses and scars ${ }^{1}$. We report on the case of a human immunodeficiency virus (HIV)-infected patient who developed a rapidly growing SCC of the scalp with a fatal outcome.

\section{CASE REPORT}

A 59-year-old white male retired driver presented with a one-year history of chronic weight loss, asthenia, anemia, disseminated scabies, herpes zoster and several recent episodes of bacterial pneumonia. He gave a past history of multiple, unprotected, sexual intercourse with male and female partners and tested positive for HIV antibodies. He had a CD4 cell count of $130 / \mathrm{mm}^{3}$ and an HIV plasma viral load of $4.9 \mathrm{log} / \mathrm{ml}$. A highly active antiretroviral regimen and Pneumocystis carinii prophylaxis were prescribed but the patient was soon lost to follow up. One year later the patient sought our service with an indurated, erythematous papule over the scalp area with a diameter of $3 \mathrm{~cm}$. The lesion was biopsied and histopathologic studies diagnosed actinic keratosis and a well differentiated SCC (Figure 1D). The patient was again lost to follow up until six months later when he presented with an extremely large infiltrating, vegetative mass over the parietal area (Figure 1A and B). Computed tomography scan study showed extensive soft tissue involvement with destruction of the underlying parietal bone (Figure 1C). Magnetic resonance imaging (not shown) found no evidence of involvement of the brain parenchyma and the superior sagittal sinus. The patient was not considered eligible for antineoplastic therapy due to the parietal bone invasion and his declining general state. He died of overwhelming sepsis two months later.

\footnotetext{
1. Serviço de Alergia e Imunologia Clínica do Hospital Universitário Gaffrée e Guinle da Universidade Federal do Estado do Rio de Janeiro, Rio de Janeiro, RJ. 2. Departamento de Anatomia Patológica da Universidade Federal do Estado do Rio de Janeiro, Rio de Janeiro, RJ. 3. Departamento de Dermatologia da Universidade Federal do Estado do Rio de Janeiro, Rio de Janeiro, RJ.

Address to: Prof. Rogério Neves-Motta. Hospital Universitário Gaffrée e Guinle/10ª enfermaria. Rua Mariz e Barros, 775, 20270-004 Rio de Janeiro, RJ

e-mail: rnmotta@hotmail.com

Recebido para publicação em 26/3/2004

Aceito em 5/8/2004
} 


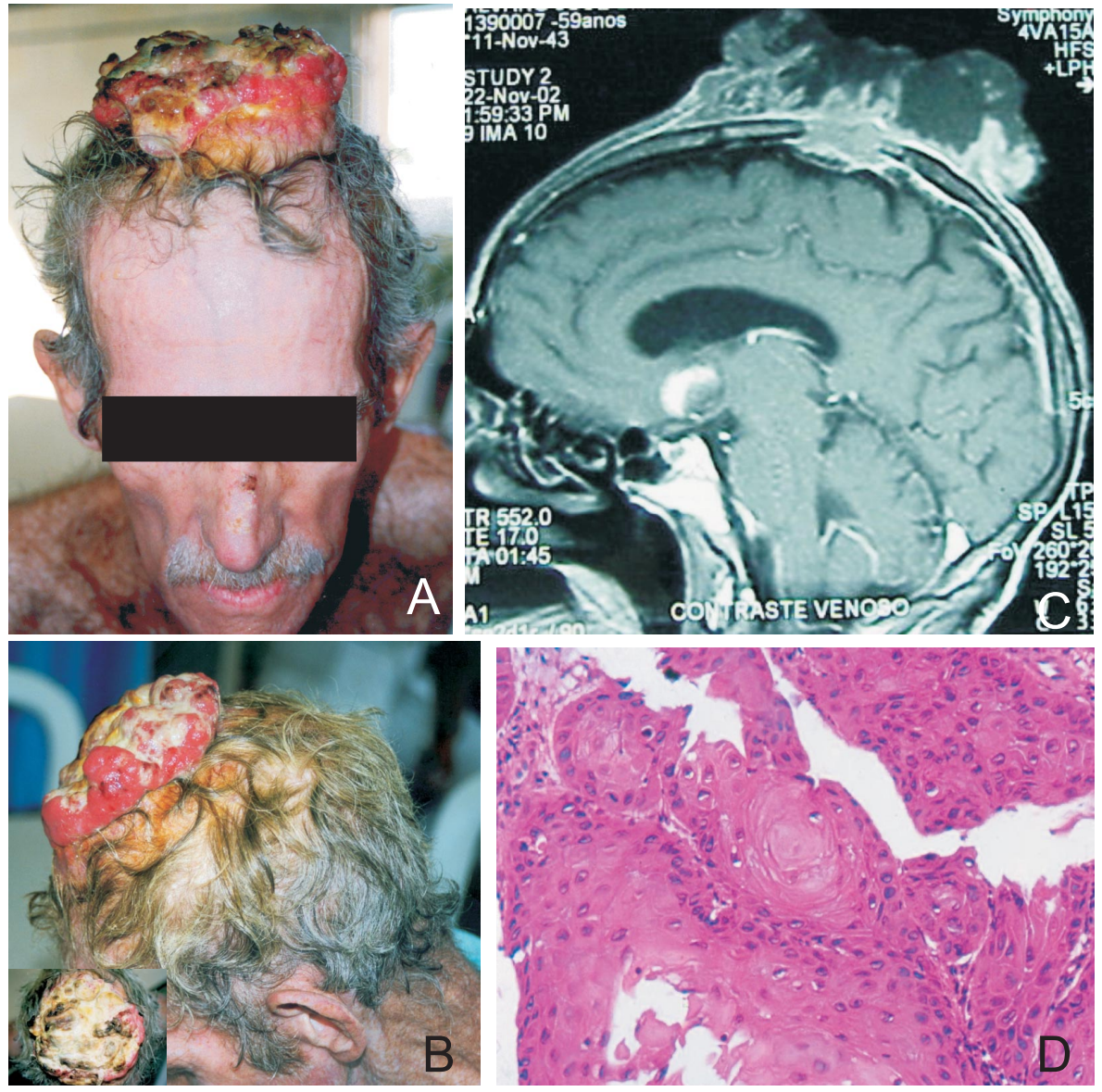

Figure 1 - Giant cutaneous squamous cell carcinoma of the scalp area. A) Frontal view of a large mass emerging from the parietal region; B) Lateral and upper (inset) view of the mass; necrotic areas can be seen; D) Sagittal view of the computed tomography scan study showing extensive soft tissue involvement and destruction of the parietal bone; D) histopathologic study demonstrates a well differentiated squamous cell carcinoma with irregular nests of epidermal cells, dermal invasion and keratin production ( $\mathrm{HE} ; 160 \mathrm{x})$.

\section{DISCUSSION}

Cutaneous squamous cell carcinoma has long been associated with conditions leading to immunosupression ${ }^{2}{ }^{13}$. Epidemiologic investigations among subjects submitted to renal ${ }^{45}$ and heart ${ }^{6}$ transplantation found the risk of SCC to be several times higher than in the general population. Patients prescribed immunosuppressant agents to treat diverse conditions such as inflammatory bowel disease and rheumatoid arthritis are also at an increased risk of developing SCC. In face of these strikingly increased incidence rates of SOC among immunosuppressed patients, Kwa and cols ${ }^{8}$ stated in a 1992 review article that it was interesting that a similar increase had not yet been found in patients with AIDS.

Highly aggressive forms of SOC are increasingly being recognized among HIV-infected patients. Isolated case reports of aggressive SOC in the context of HIV infection date back to the early years of the epidemic ${ }^{114}$. In fact, it is known that SOC can present in unusually aggressive forms in association with immunodeficiency states such as renal transplantation ${ }^{4}$ and lymphoma ${ }^{316}$. Subsequent investigations found that the major predisposing factors to the development of SOC in association with HIV infection are a fair skin type, a positive family history, a past history of excessive sun exposure, and advanced stages of immunosuppression ${ }^{910}$.
Nguyen and cols ${ }^{12}$ recently reported a case series of 10 patients diagnosed with aggressive SCCbased on rapid growth rate, a diameter of over $1.5 \mathrm{~cm}$, a history of recurrence and/or evidence of metastasis. A total of 41 SCClesions were recorded from these 10 patients. The head and neck were the most commonly involved sites (31 lesions), followed by the trunk ( 7 lesions) and extremities ( 1 lesion). Five patients had well differentiated tumors, 4 had intermediately differentiated lesions and 1 had a poorly differentiated SOC. The authors also found that patients initially undergoing combination surgery and radiation therapy or radical neck dissection had the best outcomes ${ }^{12}$.

Our patient's fulminating clinical course, in conjunction with the reports cited above, highlight the importance of a rapid diagnosis and treatment of SCClesions in HIV-infected patients if devastating growth of the primary lesion and metastatic spread are to be avoided. It is important to note that the development of SCC in HIV-infected patients seems to be determined by similar host and environmental predisposing factors as in the general population. Physicians caring for HIV-infected patients need to be aware of the possibility of an unusually aggressive behavior of SCC in such a setting. Primary prevention should be regularly instituted with sun avoidance and protection, as well as aggressive treatment of precancerous lesions such as actinic keratosis. 


\section{REFERENCES}

1. Alam M.Ratner D. Cutaneous squamous-cell carcinoma. The New England Journal of Medicine 344:975-983, 2001.

2. Dinehart SM, Chu DZ, Maners AW, Pollack SV. Immunosuppression in patients with metastatic squamous cell carcinoma from the skin. Journal of Dermatology and Surgical Oncology 16:271-274, 1990.

3. Frierson Jr HF, Deutsch BD, Levine PA. Clinicopathologic features of cutaneous squamous cell carcinomas of the head and neck in patients with chronic lymphocytic leukemia/small lymphocytic lymphoma. Human Pathology 19:1397-1402, 1988.

4. Gupta AK, Cardella CJ, Haberman HF. Cutaneous malignant neoplasms in patients with renal transplants. Archives of Dermatology 122:1288-1293, 1986.

5. Hartevelt MM, Bavinck JN, Kootte AM, Vermeer BJ, Vandenbroucke JP. Incidence of skin cancer after renal transplantation in The Netherlands. Transplantation 49:506-509, 1990.

6. Jensen P, Hansen S, Moller B, Leivestad T, Pfeffer P, Geiran O, Fauchald P, Simonsen S. Skin cancer in kidney and heart transplant recipients and different long-term immunosuppressive therapy regimens. Journal of the American Academy of Dermatology 40:177-186, 1999.

7. Kinlen LJ. Incidence of cancer in rheumatoid arthritis and other disorders after immunosuppressive treatment. American Journal of Medicine 78:4449, 1985.

8. Kwa RE, Campana K, Moy RL. Biology of cutaneous squamous cell carcinoma. Journal of the American Academy of Dermatology 26:1-26, 1992.
9. Lobo DV, Chu P, Grekin RC, Berger TG. Nonmelanoma skin cancers and infection with the human immunodeficiency virus. Archives of Dermatology 128:623-627, 1992.

10. Maurer TA, Christian KV, Kerschmann RL, Berzin B, Palefsky JM, Payne D, Tyring SK, Berger TG. Cutaneous squamous cell carcinoma in human immunodeficiency virus-infected patients. A study of epidemiologic risk factors, human papillomavirus, and p53 expression. Archives of Dermatology 133:577-583, 1997.

11. Milburn PB, Brandsma JL, Goldsman CI, Teplitz ED, Heilman EI. Disseminated warts and evolving squamous cell carcinoma in a patient with acquired immunodeficiency syndrome. Journal of the American Academy of Dermatology 19:401-405, 1988.

12. Nguyen P, Vin-Christian K, Ming ME, Berger T. Aggressive squamous cell carcinomas in persons infected with the human immunodeficiency virus. Archives of Dermatology 138:758-763, 2002.

13. Otley CC. Immunosuppression and skin cancer: pathogenetic insights, therapeutic challenges, and opportunities for innovation. Archives of Dermatology 138:827-828, 2002.

14. Overly WL, Jakubek DJ. Multiple squamous cell carcinomas and human immunodeficiency virus infection. Annals of Internal Medicine 106:334, 1987.

15. Suchniak JM, Baer S, Goldberg LH. High rate of malignant transformation in hyperkeratotic actinic keratoses. Journal of the American Academy of Dermatology 37:392-394, 1997.

16. Turner JE, Callen JP. Aggressive behavior of squamous cell carcinoma in a patient with preceding lymphocytic lymphoma. Journal of the American Academy of Dermatology 4:446-450, 1981. 